AL IBTIDA: JURNAL PENDIDIKAN GURU MI (2018) Vol 5 (1) : 53-68

DOI: http://dx.doi.org/ 10.24235/al.ibtida.snj.v5i1.2497

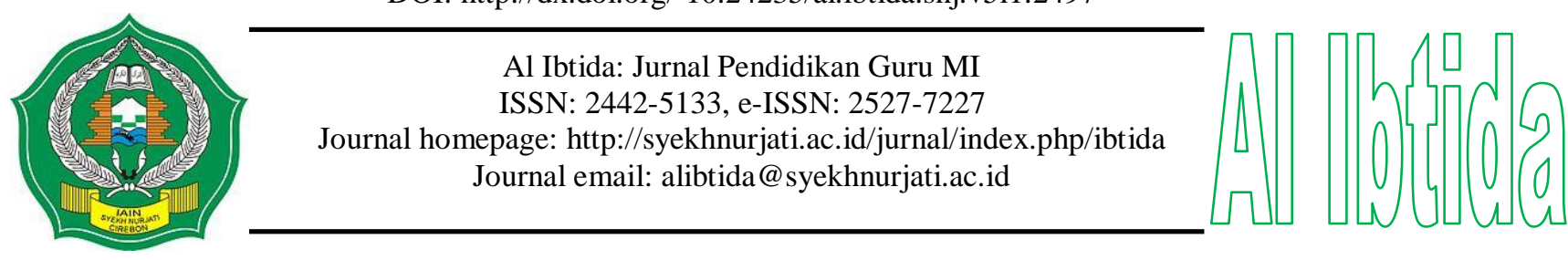

\title{
Hubungan Antara Metode Outbound Training dengan Pembentukan Karakter Kepemimpinan Siswa Kelas V di SD Sekolah Alam Bintaro
}

\author{
Fauzan* \\ *Program Studi Pendidikan Guru Madrasah Ibtidaiyah, Fakultas Ilmu Tarbiyah dan Keguruan, \\ UIN Syarif Hidayatullah Jakarta \\ Email: fauzan@uinjkt.ac.id \\ Agnes Anggraini Al Millah** \\ **Program Studi Pendidikan Guru Madrasah Ibtidaiyah, Fakultas Ilmu Tarbiyah dan Keguruan, \\ UIN Syarif Hidayatullah Jakarta \\ Email: agnesaa@gmail.com
}

Received 16 February 2018; Received in revised form: 15 May 2018; Accepted 12 June 2018

Publish Online: 28 June 2018

\begin{abstract}
Abstrak
Karakter kepemimpinan yang dimiliki oleh siswa SD Sekolah Alam Bintaro masih rendah. Rendahnya karakter kepemimpinan ini salah satunya dikarenakan minimnya rasa percaya diri atau dorongan pribadi siswa untuk menjadi seorang pemimpin, baik pemimpin di kelas maupun pemimpin dalam diskusi kelompok. Penelitian ini bertujuan untuk mengetahui hubungan antara metode pelatihan outbound dengan pembentukan karakter kepemimpinan siswa kelas V. Metode penelitian yang digunakan adalah pendekatan kuantitatif dengan teknik korelasi. Sampel dalam penelitian ini adalah seluruh siswa kelas V di SD Sekolah Alam Bintaro. Teknik pengumpulan data yang digunakan adalah angket, sedangkan observasi dan wawancara digunakan untuk memperkuat hasil angket. Sementara itu, data hasil penelitian dianalis menggunakan uji korelasi berbantuan SPSS. Berdasarkan hasil perhitungan uji korelasi antara variabel metode outbound training dan variabel karakter kepemimpinan menunjukkan bahwa nilai signifikansinya adalah sebesar $0,015<0,05$. Ini berarti bahwa Ho ditolak dan Ha diterima. Jadi metode outbound training memiliki hubungan yang positif dan signifikan terhadap karakter kepemimpinan siswa dengan tingkat keeratan sedang atau cukup baik, yaitu sebesar 0,403 .
\end{abstract}

Kata kunci: karakter kepemimpinan, metode pelatihan outbound

\begin{abstract}
The character of leadership which are owned by bintaro's natural elementary school students is still low. This lack of leadership character is due to the lack of self-confidence or personal encouragement of students to become leaders, both class leaders and leaders in group discussions. This study aims to determine the relationship between outbound training method with the leadership character building of students of class $\mathrm{V}$. The research method used a quantitative approach with correlation techniques. The sample in this
\end{abstract}


research is all students of class V in SD Sekolah Alam Bintaro (elementary school). Data collection techniques used questionnaires, while observations and interviews were used to strengthen the questionnaire results. Meanwhile, the research data was analyzed using SPSS-assisted correlation test. Based on the results of calculation of correlation test between outbound training method variables and leadership character variables indicate that the significance value is of $0.015<0.05$. This means that Ho is rejected and $\mathrm{Ha}$ accepted. Therefore, the method of outbound training has a positive and significant relationship to the leadership character of students with a moderate level of moderate or good enough, that is equal to 0.403 .

Keywords: leadership character, outbound training method

\section{PENDAHULUAN}

Pada dasarnya setiap manusia adalah seorang pemimpin (khalifah fil ardh). Di mana tugas seorang pemimpin adalah menggali potensi kepemimpinannya untuk memberikan pelayanan serta pengabdian yang diniatkan semata-mata karena Allah SWT. Di samping itu, seorang pemimpin (khalifah fil ardh) juga harus mampu memainkan perannya sebagai pembawa rahmat bagi alam semesta (rahmatan lil alamin) (Tasmara, 2006). Hal ini sebagaimana firman Allah swt dalam Q.S. Al Baqarah: 30-32 berikut ini:

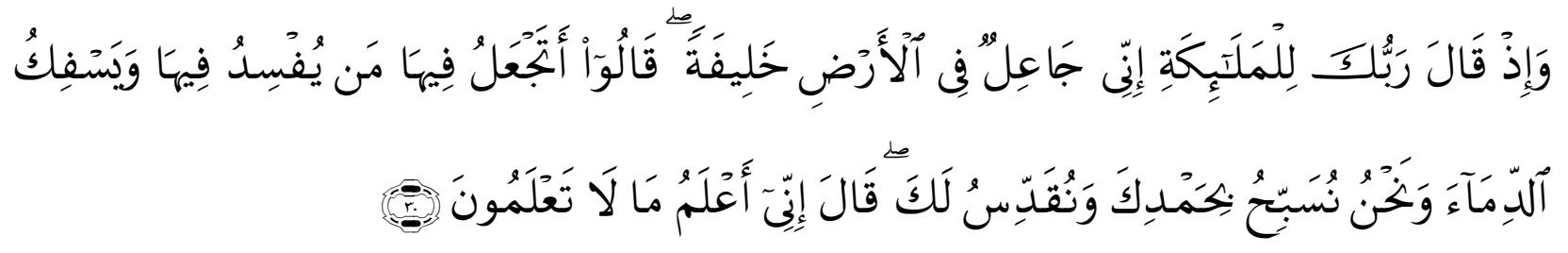

Artinya: ingatlah ketika Tuhanmu berfirman kepada Para Malaikat: "Sesungguhnya aku hendak menjadikan seorang khalifah di muka bumi." mereka berkata: "Mengapa Engkau hendak menjadikan (khalifah) di bumi itu orang yang akan membuat kerusakan padanya dan menumpahkan darah, Padahal Kami Senantiasa bertasbih dengan memuji Engkau dan mensucikan Engkau?" Tuhan berfirman: "Sesungguhnya aku mengetahui apa yang tidak kamu ketahui" (Departemen Agama RI, 2005).

Untuk menjadi seorang pemimpin, manusia harus memiliki karakter kepemimpinan yang baik. Philips dalam (Mu'in, 2011) mengatakan bahwa karakter adalah kumpulan tata nilai yang menuju pada suatu sistem, yang melandasi pemikiran, sikap, dan perilaku yang ditampilkan. Sementara itu, Robinson dalam (Uno, 2011) mendefinisikan kepemimpinan sebagai kemampuan untuk mempengaruhi suatu kelompok agar tercapai tujuan yang diharapkan.

Untuk membentuk karakter pada seorang individu harus dilakukan sedini mungkin, yakni dapat dimulai pada anak usia sekolah dasar. Karena pada jenjang sekolah dasar inilah adalah saat yang sangat tepat untuk memulai menanamkan karakter yang baik kepada siswa. Dalam penelitian yang telah dilakukan oleh (Oktarina \& et all, 2015) mengungkapkan bahwa elementary is the basic education system need to be planted the good character as a fundament (Sekolah dasar adalah sistem pendidikan dasar yang dibutuhkan untuk menanamkan karakter 
yang baik sebagai landasan). Hal ini juga senada dengan penelitian yang telah dilakukan oleh (Wijanarko, 2011) yang mengatakan bahwa penanaman karakter kepemimpinan sejak usia dini sangatlah penting agar kelak lahir calon-calon pemimpin bangsa yang baik, yang berwawasan dan berkemanusaiaan.

Namun pada kenyataannya karakter kepemimpinan yang dimiliki anak sekolah dasar masih rendah. Berdasarkan hasil observasi dan wawancara yang telah dilakukan oleh peneliti di Sekolah Alam Bintaro menunjukkan bahwa pertama, kasus rendahnya karakter kepemimpinan di Sekolah Dasar adalah minimnya rasa percaya diri atau dorongan pribadi anak untuk menjadi seorang pemimpin, baik pemimpin di kelas maupun pemimpin dalam kelompok. Hal ini dibuktikan saat ada pemilihan sebagai ketua, anak hanya mau menjadi ketua saat temantemannya yang memilih bukan karena keinginannya sendiri; kedua, masih ada anak yang malu atau tidak berani untuk melakukan komunikasi di depan kelas. Hal ini dibuktikan saat kegiatan pembelajaran, anak-anak lebih memilih untuk menunjuk temannya untuk maju daripada dirinya sendiri untuk maju berkomunikasi; ketiga, masih ada anak yang hanya mempunyai sedikit teman atau sulit bersosialisasi. Hal ini dibuktikan saat jam bermain masih ada anak lebih memilih untuk berdiam diri di kelas daripada bermain ke luar kelas. Selain itu, masih ada anak yang tidak mempunyai teman di rumah; dan yang keempat, masih ada anak yang mudah menyerah dalam proses pembelajaran. Hal ini sering terjadi pada anak-anak yang kurang pengetahuan. Mereka lebih memilih untuk menyerah dengan mengerjakan tugasnya secara tidak tepat daripada berjuang mencari jawaban yang tepat.

Selain dari keempat masalah yang telah ditemukan tersebut di atas, menurut Situmorang dalam (Wahyu, 2011) mengatakan bahwa predikat bangsa Indonesia yang ramah dan sopan menjadi kehilangan makna, manakala pembangunan karakter bangsa menjadi kabur dilanda isu kekerasan dan korupsi. Bukan hanya itu, Menurut (Rizkiani, 2012) dalam penelitiannya mengatakan bahwa rusaknya karakter karena sudah menyimpang jauh atau bertentangan dengan nilai-nilai luhur bangsa Indonesia.

Oleh karena itu, untuk membentuk karakter yang baik, anak membutuhkan pendidikan dalam kehidupan sehari-harinya. Pendidikan merupakan usaha agar manusia dapat mengembangkan potensi dirinya. Fungsi dari pendidikan nasional yang tercantum dalam Undang-Undang Republik Indonesia Nomor 20 Tahun 2003 Pasal 3 menyatakan bahwa pendidikan nasional berfungsi mengembangkan kemampuan dan membentuk watak serta peradaban bangsa yang bermartabat dalam rangka mencerdaskan kehidupan bangsa, bertujuan untuk berkembangnya potensi peserta didik agar menjadi manusia yang beriman dan bertakwa 
kepada Tuhan Yang Maha Esa, berakhlak mulia, sehat, berilmu, cakap, kreatif, mandiri, dan menjadi warga negara yang demokratis serta bertanggung jawab (Depdikbud, 2003).

Berdasarkan fungsi pendidikan nasional tersebut di atas, Ryan dan Bohlin dalam penelitiannya (Beningga \& et all, 2003) mengatakan bahwa education seeks to help students develop as persons, character development is part and parcel of the whole enterprise (pendidikan berusaha untuk membantu siswa berkembang sebagai orang, pengembangan karakter adalah bagian hakiki dari keseluruhan usaha). Menurut (Nawawi \& Hadari, 2012) kepemimpinan adalah ilmu. Hal ini berarti bahwa kepemimpinan sebagai ilmu menitikberatkan pada proses belajar dan latihan. Dengan kata lain bahwa karakter kepemimpinan tersebut dapat diperoleh melalui kegiatan pembelajaran. Dalam hal ini karakter kepemimpinan perlu dirintis dari sekolah karena dinilai sangat penting sebagai treatment awal pembentuk karakter kepemimpinan.

Namun pada kenyataannya, metode pembelajaran yang dilakukan guru untuk membentuk karakter anak masih dikategorikan belum terlihat dapat menarik minat anak. Rata-rata usia anak Indonesia saat masuk sekolah dasar adalah berusia 6 tahun dan selesai pada usia 12 tahun, dimana pada rentang usia tersebut memiliki karakteristik yang berbeda dengan anak-anak yang usianya lebih muda atau lebih tua di atasnya. Ia senang bermain, senang bergerak, senang bekerja dalam kelompok, dan senang merasakan atau melakukan sesuatu secara langsung (Wafiqni \& Latip, 2015). Oleh karena itu, sebagai seorang guru hendaknya harus mengembangkan pembelajaran yang mengandung unsur permainan, belajar dalam berkelompok, dan melibatkan siswa secara langsung dalam pembelajaran.

Salah satu metode pembelajaran yang dapat digunakan dalam pembelajaran untuk menanamkan karakter kepemimpinan adalah metode outbound training. Menurut (Djamaludin, 2002) mengatakan bahwa outbound training adalah suatu program pelatihan di alam terbuka yang mendasarkan pada prinsip "experiental learning" belajar melalui pengalaman langsung yang disajikan dalam bentuk permainan, diskusi, simulasi, dan petualangan sebagai media penyampaian materi. Menurut penelitian yang telah dilakukan oleh (Umar, 2011), (Susari, 2009), dan (Hakim \& Kumala, 2016) mengungkapkan bahwa metode ini sangat cocok dan efektif untuk menanamkan karakter kepemimpinan pada siswa. Dalam metode ini, kegiatan dimulai dari kegiatan pra training, training, dan pasca training. Banyak jenis permainan Outbond yang diterapkan di Sekolah Alam Bintaro. Salah satu permainan yang dilakukan dalam kegiatan Outbound adalah permainan Landing Net atau Jaring pendaratan. Dalam permainan ini, siswa dituntut untuk berani mengambil keputusan, berani untuk mencoba, dan percaya pada teman-temannya. Tujuan dari penelitian ini adalah untuk mengetahui hubungan antara metode 
pelatihan outbound dengan pembentukan karakter kepemimpinan siswa kelas V Sekolah Alam Bintaro.

\section{METODE PENELITIAN}

Penelitian ini merupakan penelitian deskriptif kuantitatif dengan teknik korelasional. Penelitian dilaksanakan di Sekolah Alam Bintaro Tangerang Selatan pada bulan Desembe 2016 hingga bulan Agustus 2017. Populasi dalam penelitian ini adalah seluruh siswa SD Sekolah Alam Bintaro yang berjumlah 356 siswa. Sementara itu, sampel yang digunakan dalam penelitian ini adalah 36 siswa, yang terdiri dari 18 siswa kelas V Ar Razi dan 18 siswa kelas V Az Zahrawi. Penentuan sampel ini menggunakan Purposive sampling, yakni teknik penentuan sampel dengan pertimbangan tertentu (Sugiyono, 2015).

Teknik pengumpulan data dalam penelitian ini adalah angket (kuesioner), observasi, dan wawancara. Angket dalam penelitian ini digunakan untuk memperoleh data mengenai hubungan antara metode outbound terhadap pembentukan karakter kepemimpinan siswa. Angket ini menggunakan skala likert. Angket ini diberikan kepada siswa kelas V yang berjumlah 36 siswa. Angket tersebut berisi pernyataan mengenai metode pelaksanaan outbound training dan karakter kepemimpinan siswa yang masing - masing variabel angket berisi sebanyak 30 pernyataan.

Sementara itu, teknik observasi dalam penelitian ini digunakan untuk mengukur kegiatan pelaksanaan metode outbound melalui permainan landing net. Dalam kegiatan observasi, peneliti mengamati dan menilai aktivitas kegiatan siswa, guru, dan fasilitator dalam pelaksanaan kegiatan outbound dari awal sampai kegiatan akhir pada permainan landing net. Sedangkan wawancara digunakan sebagai penguatan dari hasil angket dan observasi. Adapun teknik analisis data yang digunakan adalah uji analisis korelasi dan uji analisis skor angket.

\section{HASIL DAN PEMBAHASAN}

\section{A. Data Metode Outbound Training}

Responden dalam penelitian ini adalah seluruh siswa kelas V di SD Sekolah Alam Bintaro. Data diperoleh melalui penyebaran angket yang terdiri dari 30 item dengan jumlah responden 36 orang. Hasil data yang diperoleh sebagai berikut: 
Tabel 1. Skor Total Metode Outbound Training (X)

\begin{tabular}{|c|c|c|}
\hline \multicolumn{3}{|c|}{ Statistics } \\
\hline \multicolumn{3}{|l|}{ X } \\
\hline \multirow[t]{2}{*}{$\mathrm{N}$} & Valid & 36 \\
\hline & \multicolumn{2}{|l|}{ Missing } \\
\hline & & 86,78 \\
\hline & & 89,50 \\
\hline & & 91 \\
\hline & eviation & 8,702 \\
\hline & nce & 75,721 \\
\hline & & 39 \\
\hline & num & 62 \\
\hline & mum & 101 \\
\hline $\mathrm{St}$ & & 3124 \\
\hline
\end{tabular}

Dari tabel 1 di atas dapat diketahui bahwa rata-rata metode outbond training sebesar 86,78, median sebesar 89,50, dan modus sebesar 91. Sementara itu skor tertinggi yang diperoleh sebesar 101 dan skor terendah sebesar 62. Dari hasil tersebut, dapat disajikan dalam bentuk tabel distribusi frekuensi seperti tabel berikut ini:

Tabel 2. Distribusi Frekuensi Metode Outbound Training (X)

\begin{tabular}{ccc}
\hline No & Kelas Interval & Frekuensi \\
\hline 1 & $62-68$ & 1 \\
\hline 2 & $69-75$ & 3 \\
\hline 3 & $76-82$ & 9 \\
\hline 4 & $83-89$ & 5 \\
\hline 5 & $90-96$ & 15 \\
\hline 6 & $97-103$ & 3 \\
\hline & Jumlah & 36 \\
\hline
\end{tabular}

Berdasarkan tabel 2 dapat diketahui bahwa distribusi frekuensi metode outbound training tertinggi berada pada kelas interval nomor 5 yang mempunyai rentang 90-96 dengan jumlah sebanyak 15 siswa.

Dari hasil distribusi frekuensi, selanjutnya peneliti melakukan pengelompokkan kecenderungan skor variabel metode outbound training yang diperoleh berdasarkan perhitungan mean dan standar deviasi hipotetik sebagai berikut:

$$
\begin{aligned}
\mathrm{M}_{\text {hip }} & =\frac{1}{2}\left(i_{\max }+i_{\min }\right) \Sigma \\
& =\frac{1}{2}(4+1) 30 \\
& =75 \\
\mathrm{SD}_{\text {hip }} & =\frac{1}{6}\left(i_{\max }-i_{\min }\right) \Sigma \\
& =\frac{1}{6}(4-1) 30 \\
& =15
\end{aligned}
$$


Keterangan:

$\mathrm{M}_{\text {hip }}$ : Rata-rata hipotetik

SD hip: Standar deviasi hipotetik

$\mathrm{I}_{\max }$ : Skor maksimal item

$\mathrm{I}_{\min }:$ Skor minimal item

$\sum \quad$ : Jumlah item valid lapangan.

Kategori pengukuran pada subjek dibagi menjadi tiga kategori, yaitu kategori tinggi, sedang, dan rendah. Untuk mengetahui skor kategori maka diperoleh sebagai berikut:
a) Rendah $\quad=X \leq\left(\mathrm{M}_{\text {hip }}-1 \mathrm{SD}_{\text {hip }}\right)$
$=\mathrm{X} \leq(75-15)$
$=\mathrm{X} \leq 60$
b) Sedang = $=\left(\mathrm{M}_{\text {hip }}-1 \mathrm{SD}_{\text {hip }}\right)<\mathrm{X} \leq\left(\mathrm{M}_{\text {hip }}+1 \mathrm{SD}_{\text {hip }}\right)$
$=(75-15)<\mathrm{X} \leq(75+15)$
$=60<\mathrm{X} \leq 90$
c) Tinggi $=X>\left(\mathrm{M}_{\text {hip }}+1 \mathrm{SD}_{\text {hip }}\right)$
$=X>(75+15)$
$=\mathrm{X}>90$

Dari hasil tersebut, berikut tabel distribusi frekuensi kategori kecenderungan metode outbound training:

Tabel 3. Distribusi Frekuensi Kategori Kecenderungan Metode Outbound Training (X)

\begin{tabular}{cccccc}
\hline No & Kategori & Kriteria & Interval & $\mathrm{F}$ & $\%$ \\
\hline 1 & Rendah & $\mathrm{X} \leq\left(\mathrm{M}_{\text {hip }}-1 \mathrm{SD}_{\text {hip }}\right)$ & $\mathrm{X} \leq 60$ & 0 & $0 \%$ \\
\hline 2 & Sedang & $\left(\mathrm{M}_{\text {hip }}-1 \mathrm{SD}_{\text {hip }}\right)<\mathrm{X} \leq\left(\mathrm{M}_{\text {hip }}+1 \mathrm{SD}_{\text {hip }}\right)$ & $\begin{array}{c}60<\mathrm{X} \leq \\
90\end{array}$ & 20 & $55,56 \%$ \\
\hline 3 & Tinggi & $\mathrm{X}>\left(\mathrm{M}_{\text {hip }}+1 \mathrm{SD}_{\text {hip }}\right)$ & $\mathrm{X}>90$ & 16 & $44,44 \%$ \\
\hline \multicolumn{7}{c}{ Total } & & 36 & $100 \%$ \\
\hline
\end{tabular}

Berdasarkan tabel 3 di atas, dapat disimpulkan bahwa frekuensi kategori kecenderungan metode outbound training (X) paling banyak pada kategori sedang dengan frekuensi 20 dari 36 responden dengan persentase sebesar 55,56\%.

Sebagai penguatan dari hasil angket, untuk mengukur pelaksanaan metode outbound training peneliti melakukan observasi pada pelaksanaan kegiatannya. Adapun data skor lembar observasi metode outbound training dari hasil penelitian sebagai berikut: 
Tabel 4. Skor Observasi Metode Outbound Training (X)

\begin{tabular}{ccc}
\hline No & Observasi Ke- & Skor Total \\
\hline 1 & 1 & 57 \\
\hline 2 & 2 & 54 \\
\hline 3 & 3 & 57 \\
\hline 4 & 4 & 60 \\
\hline & Mean & 57 \\
\hline
\end{tabular}

Kecenderungan skor variabel metode outbound training dapat diperoleh berdasarkan perhitungan mean dan standar deviasi hipotetik berikut ini:

$$
\begin{aligned}
\mathrm{M}_{\text {hip }} & =\frac{1}{2}\left(i_{\max }+i_{\min }\right) \Sigma \\
& =\frac{1}{2}(4+1) 19 \\
& =47,5 \\
\mathrm{SD}_{\text {hip }} & =\frac{1}{6}\left(i_{\max }-i_{\min }\right) \Sigma \\
& =\frac{1}{6}(4-1) 19 \\
& =9,5
\end{aligned}
$$

Kategori pengukuran pada subjek dibagi menjadi tiga kategori, yaitu kategori tinggi, sedang, dan rendah. Untuk mengetahui skor kategori maka diperoleh dari pembagian sebagai berikut:

a) Rendah $=\mathrm{X} \leq\left(\mathrm{M}_{\text {hip }}-1 \mathrm{SD}_{\text {hip }}\right)$

$$
\begin{aligned}
& =X \leq(47,5-9,5) \\
& =X \leq 38
\end{aligned}
$$

b) Sedang $=\left(\mathrm{M}_{\text {hip }}-1 \mathrm{SD}_{\text {hip }}\right)<\mathrm{X} \leq\left(\mathrm{M}_{\text {hip }}+1 \mathrm{SD}_{\text {hip }}\right)$

$$
\begin{aligned}
& =(47,5-9,5)<X \leq(47,5+9,5) \\
& =38<X \leq 57
\end{aligned}
$$

c) Tinggi $=X>\left(M_{\text {hip }}+1 \mathrm{SD}_{\text {hip }}\right)$

$$
\begin{aligned}
& =X>(47,5+9,5) \\
& =X>57 .
\end{aligned}
$$

Dari hasil tersebut, berikut tabel distribusi frekuensi kategori kecenderungan metode outbound training:

Tabel 5. Distribusi Frekuensi Kategori Kecenderungan Metode Outbound Training (X)

\begin{tabular}{lc}
\hline Skala Penilaian & Kategori Metode Outbound Training \\
\hline $\mathrm{X} \leq 38$ & Rendah/Kurang \\
\hline $38<\mathrm{X} \leq 57$ & Sedang/Cukup \\
\hline $\mathrm{X}>57$ & Tinggi/Baik \\
\hline
\end{tabular}


Berdasarkan tabel 5 dapat disimpulkan bahwa frekuensi kategori kecenderungan metode outbound training $(\mathrm{X})$ berada pada ketegori sedang dengan skor rata-rata sebesar 57.

Selain observasi, peneliti melakukan penguatan data dari angket melalui wawancara. Peneliti melakukan wawancara kepada Kepala Sekolah, Wali Kelas V Ar Razi, dan Wali Kelas Kelas V Az Zahrawi. Wawancara ini dilakukan untuk mengetahui pelaksanaan kegiatan metode outbound training. Peneliti mewawancarai Pak Wisnu sebagai wali kelas V Ar Razi. Menurut beliau, secara keseluruh kegiatan outbound yang diterapkan di sekolah ini sudah berjalan dengan baik. Dalam pelaksanaan kegiatan outbound ini sudah ada urutanurutan kegiatannya. Pertama dimulai dari apel pagi, dilanjutkan dengan mentoring, streching, snack, lalu penjelasan kegiatan outbound yang akan dilakukan dan di akhir kegiatan ada kegiatan refleksi.

Selain itu, peneliti mewawancarai pak Luthfi sebagai wali kelas V Az Zahrawi. Menurut beliau, dari kegiatan outbound yang sudah diterapkan SD Sekolah Alam Bintaro ini sudah bisa menjadi pembeda antara aktivitas siswa Sekolah Alam dengan sekolah lainnya. Hal ini terlihat pada keberanian yang dimiliki siswa Sekolah Alam Bintaro. Hal tersebut dipertegas oleh pernyataan dari Kepala SD Sekolah Alam Bintaro yaitu Ibu Siti Aisah yang menyatakan bahwa metode outbound yang diterapkan di sekolah ini mempunyai prosedur dalam kegiatan outbound yang akan dilaksanakan. Sebelum melakukan kegiatan fasilitator melakukan briefing atau arahan dengan anak-anak terkait kegiatan yang akan dilaksanakan. Lalu fasilitator juga melakukan safety prosedure mengenai alat-alat yang akan dilakukan dalam kegiatan outbound. Setelah fasilitator melakulan kegiatan, di akhir kegiatan outbound ada kegiatan reflection terkait kegiatan yang sudah dilakukan.

Selain mewawancarai Kepala Sekolah dan Guru, peneliti mewawancarai 5 perwakilan siswa dari kelas V Sekolah Dasar Alam Bintaro yaitu Viola, Eyza, Malik, Bagas, dan Wafa. Hasil wawancara dengan 5 perwakilan siswa ini digunakan sebagai pengutan dari data angket. Pernyataan dari kelima siswa ini menjelaskan tentang urutan kegiatan yang dilakukan pada kegiatan outbound training. Malik menjelaskan bahwa sebelum kegiatan outbound dimulai, ada kegiatan apel pagi yang dilaksanakan antara 15 sampai dengan 20 menit. Ia juga menambahkan bahwa sebelum kegiatan outbound dimulai, biasanya guru menjelaskan peraturan-peraturan dalam permaianan outbound yang akan dilaksanakan. Selain itu, Eyza, Bagas, dan Wafa menambahkan bahwa ada kegiatan streaching, sharing day, snack, baris-berbaris serta pemakaian alat seperti webbing dan helm.

Dalam pelaksanaan kegiatan outbound, Viola menjelaskan bahwa setiap permainan menggunakan instalasi, biasanya anak-anak diminta untuk mengantre menunggu giliran. 
Eyza dan Wafa pun sependapat dengan jawaban Viola. Pada saat kegiatan, menurut Eyza dan Bagas tugas Guru sebagai pengawas kegiatan, membantu pemakaian alat, mendokumentasikan kegiatan, dan menyiapkan perlengkapan.

Viola menyebutkan bahwa di akhir kegiatan outbound, siswa membantu merapikan perlengkapan dan memahami nilai atau hikmah dari kegiatan yang telah dilakukan. Eyza pun menambahkan bahwa di akhir kegiatan siswa saling memberikan semangat dan melakukan diskusi. Lalu, ada kegiatan Free Play yang disebut oleh Malik.

\section{B. Data Karakter Kepemipinan}

Responden dalam penelitian ini adalah seluruh siswa kelas 5 di Sekolah Dasar Alam Bintaro. Data diperoleh melalui penyebaran angket yang terdiri dari 30 item dengan jumlah responden 36 orang. Hasil data yang diperoleh sebagai berikut:

Tabel 6. Skor Total Karakter Kepemimpinan

\begin{tabular}{|c|c|c|}
\hline \multicolumn{3}{|c|}{ Statistics } \\
\hline \multicolumn{3}{|l|}{$Y$} \\
\hline \multirow[t]{2}{*}{$\mathrm{N}$} & Valid & 36 \\
\hline & Missing & 0 \\
\hline & & 86,72 \\
\hline & & 85,00 \\
\hline & & 85 \\
\hline & eviation & 7,891 \\
\hline & nce & 62,263 \\
\hline & & 33 \\
\hline & num & 71 \\
\hline & num & 104 \\
\hline $\mathrm{Su}$ & & 3122 \\
\hline
\end{tabular}

Dari tabel 6 di atas dapat diketahui bahwa rata-rata skor karakter kepemimpinan sebesar 86,72, median 85 dan modus 85. Skor tertinggi yang diperoleh sebesar 104 dan skor terendah sebesar 71. Dari hasil tersebut, dapat disajikan dalam bentuk tabel distribusi frekuensi seperti tabel berikut ini:

Tabel 7. Distribusi Frekuensi Karakter Kepemimpinan

\begin{tabular}{ccc}
\hline No & Kelas Interval & Frekuensi \\
\hline 1 & $71-76$ & 3 \\
\hline 2 & $77-82$ & 8 \\
\hline 3 & $83-88$ & 11 \\
\hline 4 & $89-94$ & 8 \\
\hline 5 & $95-100$ & 4 \\
\hline 6 & $101-106$ & 2 \\
\hline & Jumlah & 36 \\
\hline
\end{tabular}


Berdasarkan tabel 7 tersebut dapat diketahui bahwa distribusi frekuensi karakter kepemimpinan tertinggi berada pada kelas interval nomor 3 yang mempunyai rentang 83-88 dengan jumlah sebanyak 11 siswa.

Dari hasil distribusi frekuensi, selanjutnya peneliti melakukan pengelompokkan kecenderungan skor variabel karakter kepemimpian yang diperoleh berdasarkan perhitungan mean dan standar deviasi hipotetik sebagai berikut:

$$
\begin{aligned}
\mathrm{M}_{\text {hip }} & =\frac{1}{2}\left(i_{\max }+i_{\min }\right) \Sigma \\
& =\frac{1}{2}(4+1) 30 \\
& =75 \\
\mathrm{SD}_{\text {hip }} & =\frac{1}{6}\left(i_{\max }-i_{\min }\right) \Sigma \\
& =\frac{1}{6}(4-1) 30 \\
& =15
\end{aligned}
$$

Keterangan:

$$
\begin{aligned}
& \mathrm{M}_{\text {hip }} \quad: \text { Rata-rata hipotetik } \\
& \mathrm{SD}_{\text {hip }}: \text { Standar deviasi hipotetik } \\
& \mathrm{I}_{\max }: \text { Skor maksimal item } \\
& \mathrm{I}_{\min }: \text { Skor minimal item } \\
& \sum \quad \text { Jumlah item valid }
\end{aligned}
$$

Kategori pengukuran pada subjek dibagi menjadi tiga kategori, yaitu kategori tinggi, sedang, dan rendah. Untuk mengetahui skor kategori maka diperoleh dari pembagian sebagai berikut:

a) $\operatorname{Rendah}=\mathrm{X} \leq\left(\mathrm{M}_{\text {hip }}-1 \mathrm{SD}_{\text {hip }}\right)$

$$
\begin{aligned}
& =X \leq(75-15) \\
& =X \leq 60
\end{aligned}
$$

b) Sedang $=\left(\mathrm{M}_{\text {hip }}-1 \mathrm{SD}_{\text {hip }}\right)<\mathrm{X} \leq\left(\mathrm{M}_{\text {hip }}+1 \mathrm{SD}_{\text {hip }}\right)$

$$
\begin{aligned}
& =(75-15)<X \leq(75+15) \\
& =60<X \leq 90
\end{aligned}
$$

c) Tinggi $=X>\left(M_{\text {hip }}+1 \mathrm{SD}_{\text {hip }}\right)$

$$
\begin{aligned}
& =X>(75+15) \\
& =X>90
\end{aligned}
$$

Dari hasil tersebut, berikut tabel distribusi frekuensi kategori kecenderungan metode karakter kepemimpinan: 
Tabel 8. Distribusi Frekuensi Kategori Kecenderungan Karakter Kepemimpinan

\begin{tabular}{cccccc}
\hline No & Kategori & Kriteria & Interval & $\mathrm{F}$ & $\%$ \\
\hline 1 & Rendah & $\mathrm{X} \leq\left(\mathrm{M}_{\text {hip }}-1 \mathrm{SD}_{\text {hip }}\right)$ & $\mathrm{X} \leq 60$ & 0 & $0 \%$ \\
\hline 2 & Sedang & $\left(\mathrm{M}_{\text {hip }}-1 \mathrm{SD}_{\text {hip }}\right)<\mathrm{X} \leq\left(\mathrm{M}_{\text {hip }}+1 \mathrm{SD}_{\text {hip }}\right)$ & $60<\mathrm{X} \leq 90$ & 25 & $69,44 \%$ \\
\hline 3 & Tinggi & $\mathrm{X}>\left(\mathrm{M}_{\text {hip }}+1 \mathrm{SD}_{\text {hip }}\right)$ & $\mathrm{X}>90$ & 11 & $30,56 \%$ \\
\hline \multicolumn{2}{c}{ Total } & & 36 & $100 \%$ \\
\hline
\end{tabular}

Berdasarkan tabel 8 di atas, dapat disimpulkan bahwa frekuensi kategori kecenderungan metode karakter kepemimpinan (Y) paling banyak pada kategori sedang dengan frekuensi 25 dari 36 responden dengan persentase sebesar 69,44\%.

Selain angket, peneliti melakukan penguatan data dari angket melalui wawancara. Peneliti melakukan wawancara kepada Kepala Sekolah, Wali Kelas V Ar Razi, dan Wali Kelas Kelas V Az Zahrawi. Wawancara ini dilakukan untuk mengetahui karakter kepemimpinan siswa pada kelas V. Pertama, peneliti mewanwacarai Kepala SD Sekolah Alam Bintaro yaitu Ibu Siti Aisah. Beliau menyebutkan bahwa SD Sekolah Alam Bintaro ini menerapkan konsep kepemimpinan dalam konsep Pendidikan di sekolah ini. Dalam menerapkan konsep kepemimipinan, sekolah ini menggunakan outbound sebagai alat terbentuknya karakter kepemimpinan anak.

Kedua, peneliti mewawancarai pak Luthfi sebagai wali kelas V Az Zahrawi. Secara keseluruhan beliau menyebutkan bahwa memang masih ada kendala dalam membentuk karakter kepemimpinan siswa seperti ada siswa yang mudah menyerah, membutuhkan waktu yang lama untuk memahami pelajaran, adanya pertengkaran antar siswa, dan ada siswa yang kurang pintar dalam berkomunikasi. Namun, hal tersebut bisa diatasi dengan berbagai treatment yang dilakukan baik oleh guru ataupun kegiatan yang ada di sekolah ini.

Ketiga, peneliti mewawancarai Pak Wisnu sebagai wali kelas V Ar Razi. Secara keseluruhan beliau sependapat dengan pernyataan pak Luthfi. Beliau juga mempertegas bahwa selain kendala yang disebutkan Pak Luthfi, ada siswa-siswa yang dominan pada indikator karakter kepemimpinannya dari siswa lainnya. Beliau menambahkan pula bahwa sosialisasi siswa di sekolah ini tergolong merata dan baik karena banyak kegiatan yang melibatkan seluruh siswa.

Selain mewawancarai Kepala Sekolah dan Guru, peneliti mewawancarai 5 perwakilan siswa dari kelas V Sekolah Dasar Alam Bintaro yaitu Viola, Eyza, Malik, Bagas, dan Wafa. Hasil wawancara dengan 5 perwakilan siswa ini digunakan sebagai penguatan dari data angket untuk mengukur variabel karakter kepemimpinan siswa. Kelima siswa menyatakan bahwa mereka tidak mudah menyerah dalam mengerjakan tugas yang diberikan. 
Dari kelima siswa, dua siswa menyatakan bahwa ia akan melakukan diskusi atau menanyakan tugas yang sulit tersebut kepada orang yang lebih bisa. Sementara tiga lainnya, menyatakan bahwa ia akan mengerjakan tugasnya walaupun jawaban yang diberikan salah.

Terkait stabilitas emosi siswa. Dari kelima siswa, tiga siswa laki-laki yang diwawancarai menyatakan bahwa apabila mereka mendapatkan masalah dengan teman, mereka akan diam terlebih dahulu. Lalu, apabila masalah semakin besar, mereka akan menyelesaikannya. Lain hal dengan dua siswi perempuan yang diwawancarai. Mereka lebih meledak-ledak emosinya saat mendapat masalah dengan temannya. Kelima siswa mempunyai kelebihan dan kekurangan masing-masing.

Dari kelima siswa, tiga siswa menyatakan bahwa kekurangan yang dimilikinya adalah rendahnya percaya diri mereka sehingga membuatnya menjadi lebih pendiam. Sedangkan dua lainnya yaitu Malik dan Viola memiliki kelemahan pada stabilitas emosinya. Untuk tingkat kejujurannya, kelima siswa sependapat bahwa mereka pernah berbohong dengan alasan yang berbeda-beda. Sementara pada keinginan pribadi untuk menjadi pemimpin, dua diantara lima siswa berani untuk mencalonkan. Sementara tiga lainnya, tidak berani untuk mencalonkan.

Pada tingkat objektif siswa, dua siswa memilih temannya dalam pemilihan ketua. Dan tiga lainnya memilih orang yang lebih mempunyai kelebihan dan tidak memandang teman. Sementara untuk keterampilan sosialisasi siswa, hanya dua siswa dari lima siswa yang mempunyai teman di rumah. Tiga siswa lainnya tidak mempunyai teman di rumah.

Pada keterampilan berkomunikasi siswa, hasil dari wawancara menyebutkan bahwa empat dari lima siswa menyatakan tidak berani atau malu-malu untuk berbicara di depan kelas. Sementara hanya satu siswa dari lima siswa yang diwawancarai yang berani untuk berbicara di depan kelas.

\section{Uji Hipotesis}

Uji hipotesis dalam penelitian ini menggunakan analisis korelasi. Adapun perhitungan analisis korelasi sebagai berikut:

Tabel 9. Hasil Analisis Korelasi

\begin{tabular}{|c|c|c|c|}
\hline \multicolumn{4}{|c|}{ Correlations } \\
\hline & & X & $\mathrm{Y}$ \\
\hline \multirow[t]{3}{*}{$\mathrm{X}$} & Pearson Correlation & 1 &, $403^{*}$ \\
\hline & Sig. (2-tailed) & &, 015 \\
\hline & $\mathrm{N}$ & 36 & 36 \\
\hline \multirow[t]{3}{*}{$\mathrm{Y}$} & Pearson Correlation &, $403^{*}$ & 1 \\
\hline & Sig. (2-tailed) &, 015 & \\
\hline & $\mathrm{N}$ & 36 & 36 \\
\hline
\end{tabular}


Berdasarkan tabel 9 di atas, diperoleh angka koefisien korelasi sebesar 0,403. Tanda bintang satu menunjukkan bahwa korelasi signifikansi terletak pada level 0,05. Nilai signifikansi yang didapat adalah 0,015 dan nilai tersebut lebih kecil dari 0,05, maka terjadi hubungan yang signifikan. Angka indeks korelasi bertanda plus maka korelasi tersebut positif dan arah korelasi satu arah. Artinya, penelitian ini menunjukkan hubungan positif yaitu jika metode outbound training meningkat, maka pembentukan karakter kepemimpinan siswa juga meningkat.

Koefisien korelasi antara variabel metode outbound training dengan karakter kepemimpinan siswa sebesar 0,403. Dari hasil tersebut, menunjukkan bahwa tingkat keeratan hubungan berada pada kategori hubungan sedang atau cukup karena terletak antara nilai 0,40 $-<0,70$.

Dari hasil perhitungan analisis korelasi antara metode outbound training dengan pembentukan karakter kepemimpinan siswa di SD Sekolah Alam Bintaro dapat disimpulkan bahwa terdapat hubungan yang positif dan signifikan dengan tingkat keeratan sedang atau cukup antara metode outbound training dengan pembentukan karakter kepemimpinan siswa. Dari hubungan yang menyatakan positif berarti jika metode outbound training meningkat, maka pembentukan karakter kepemimpinan siswa juga meningkat.

Berdasarkan uraian hasil penelitian di atas menunjukkan bahwa dari hasil analisis data angket pada variabel metode outbound training menunjukkan distribusi frekuensi kecenderungan persentase terbesar pada kategori sedang dengan persentase sebesar 55,56\%. Hal ini didukung dengan hasil analisis lembar observasi yang dilakukan oleh peneliti, variabel metode outbound training memperoleh skor rata-rata sebesar 57 yang menunjukkan kategori sedang atau cukup. Adapun dari hasil analisis data angket pada variabel karakter kepemimpinan menunjukkan bahwa distribusi frekuensi kecenderungan persentase terbesar pada kategori sedang dengan persentase sebesar 69,44\%. Dengan demikian, dapat dinyatakan bahwa metode outbound training dan karakter kepemimpinan siswa kelas V di SD Sekolah Alam Bintaro dalam kategori sedang atau cukup baik. Hal ini karena memang metode outbond training menurut penelitian yang dilakukan oleh (Susari, 2009), (Hakim \& Kumala, 2016), (Umar, 2011), dan ( Widarnandana \& Simarmata , 2015) sangat cocok dan efektif untuk menanamkan karakter kepemimpinan pada siswa. Pengalaman yang diperoleh dari kegiatan outbound dapat memberikan masukan yang positif dalam perkembangan kedewasaan seorang siswa.

Sementara itu, penggunaan metode outbond training untuk menanamkan karakter kepemimpinan siswa memiliki hubungan yang positif dan signifikan dengan tingkat keeratan sedang atau cukup baik, yaitu sebesar 0,403. Hal ini dikarenakan salah satu fungsi dan tujuan 
dari outbond training menurut penelitian yang dilakukan oleh (Umar, 2011) adalah untuk meningkatkan jiwa kepemimpinan. Karena dalam outbond training seseorang akan dilatih untuk mampu bekerja dalam tim, berkomunikasi yang baik dengan teman sesama anggota kelompok, dilatih untuk mengambil sebuah keputusan dan lain sebagainya. Hasil penelitian ini juga sejalan dengan penelitian yang telah dilakukan oleh Wijanarko (2011) yang mengungkapkan bahwa metode outbond training berpengaruh positif terhadap pembentukan karakter kepemimpinan siswa.

\section{SIMPULAN}

Berdasarkan hasil penelitian yang telah diuraikan di atas dapat ditarik kesimpulan sebagai berikut:

1. Hasil analisis data angket pada metode outbound training dan karakter kepemimpinan siswa kelas V di SD Sekolah Alam Bintaro dalam kategori sedang atau cukup baik, yakni sebesar $55,56 \%$ dan $69,44 \%$.

2. Hasil perhitungan uji korelasi antara variabel metode outbound training dan variabel karakter kepemimpinan menunjukkan bahwa nilai signifikansinya adalah sebesar 0,015 $<0,05$. Ini berarti bahwa metode outbound training memiliki hubungan yang positif dan signifikan terhadap karakter kepemimpinan siswa dengan tingkat keeratan sedang atau cukup baik, yaitu sebesar 0,403 .

\section{DAFTAR PUSTAKA}

Beningga, J. S., \& et all. (2003). The Relationship of Character Education Implementation and Academic Achievement in Elementary Schools. Journal of Research in Character Education, 01(01), 20.

Departemen Agama RI. (2005). Al Qur'an dan Terjemahannya. Bandung: PT. Syaamil Cipta Media.

Depdikbud. (2003). UU No 20 Tahun 2003 tentang Sistem Pendidikan Nasional. Jakarta: Depdikbud.

Djamaludin, A. (2002). Outbond Manajemen Training. Yogyakarta: UII Press.

Hakim, A. R., \& Kumala, F. N. (2016). Pengembangan Karakter Melalui Kegiatan Outbond. Jurnal Moral Kemasyarakatan, 1(2), 173-182.

Mu'in, F. (2011). Pendidikan Karakter: Konstruksi Teoritik dan Praktik. Yogyakarta: Ar Ruzz Media.

Nawawi, H., \& Hadari, M. M. (2012). Kepemimpinan yang Efektif. Yogyakarta: Gadjah Mada University Press.

Oktarina, N., \& et all. (2015). Character Education Evaluation Model Based on School Culture for Elementary School. Journal of Research and Method Education, 05(05), 11. 
Rizkiani, A. (2012). Pengaruh Sistem Boarding School Terhadap Pembentukkan Karakter Peserta Didik. Jurnal Pendidikan, 06(01), 11.

Sugiyono. (2015). Metode Penelitian Kuantitatif, Kualitatif, dan R\&D. Bandung: Alfabeta.

Susari, H. D. (2009). Implementasi Kegiatan Outbound Dalam Upaya Pembentukan Perilaku Sosial dan Emosional Anak Usia Dini. Jurnal Pendidikan, 15(1).

Tasmara, T. (2006). Spiritual Centered Leadership (Kepemimpinan Berbasis Spiritual). Jakarta: Gema Insani.

Umar, T. (2011). Pengaruh Outbond Training Rasa Percaya Diri, Kepemimpinan dan Kerjasama Tim. Jurnal Ilmiah Spirit, 11(3), 1-10.

Uno, H. (2011). Teori Motivasi dan Pengukurannya: Analisis di Bidang Pendidikan. Jakarata: Bumi Aksara.

Wafiqni, N., \& Latip, A. E. (2015). Psikologi Perkembangan Anak Usia MI/SD: Teori dan Grand Design Pendidikan Berbasis Perkembangan. Jakarta: UIN Press.

Wahyu. (2011). Masalah dan Usaha Membangun Karakter Bangsa. Jurnal Komunitas, 03(02), 138-149.

Widarnandana , I. D., \& Simarmata , N. (2015). Pengaruh Outbond Terhadap Efikasi Diri pada Mahasiswa. Jurnal Psikologi Udayana, 2(2), 151-162.

Wijanarko, W. (2011). Pengaruh Metode Outbond terhadap Pembentukan Karakter Kepemimpinan Siswa Sekolah Alam Indonesia. Skripsi: UIN Syarif Hidayatullah Jakarta. 